\title{
A review on sustainability and quality of biochar production from oil palm biomass in Malaysia using thermal conversion technology
}

\author{
Mustakimah Mohamed ${ }^{\mathrm{a}}$, and Suzana Yusup*b \\ ${ }^{a}$ HICoE-Centre for Biofuel and Biochemical Research (CBBR), Institute of Self-Sustainable Building, Universiti Teknologi \\ PETRONAS, 32610 Seri Iskandar, Perak, Malaysia. \\ ${ }^{b}$ HICoE-Centre for Biofuel and Biochemical Research (CBBR), Institute of Self-Sustainable Building, Chemical Engineering \\ Department, Universiti Teknologi PETRONAS, 32610 Seri Iskandar, Perak, Malaysia.
}

\begin{abstract}
Oil palm empty fruit bunch (EFB), mesocarp fiber (MF), palm kernel shell (PKS), oil palm trunk (OPT) and oil palm frond (OPF) are the common solid lignocellulosic biomass generated from oil palm industries. A palm oil plantation was estimated to generate 36.5 ton of dry biomass in each hectare every year which suggesting the abundancy of these wastes. Feedstock feasibility and common properties as a carbon-rich material, have initiated an interest to utilize these biomass for biochar production. This paper provides a review on the developed thermal conversion technologies to synthesize biochar from oil palm biomass and includes the respective product quality such as carbon contents, yield and other physicochemical properties. The sustainability of oil palm biomass as the feedstock for biochar production in Malaysia were also described by providing the overview on biomass availability, biomass industry value chain and respective characteristics. Determining appropriate type of biomass and applying effective type of thermal conversion technologies produce biochar with good physicochemical qualities. This review observed that lignin in biomass contributes significantly to biochar production and slow pyrolysis technique is a promising technology to yield a good quality of biochar.
\end{abstract}

\section{Oil palm industry in Malaysia}

Malaysia contributes almost $28 \%$ of world palm oil production and shared $33 \%$ of the world exports [1]. An amount of 98.42 thousand tons of fresh fruit bunch (FFB) was obtained in 2018, which contributed to 19.5 million ton production of crude palm oil (CPO) [2]. Fig. 1 illustrated the production of oil palm products from four types of oil palm biomass which are $\mathrm{CPO}$, palm kernel (PK), palm kernel oil (PKO) and palm kernel cake (PKC). The production of CPO varies from 17 to 20 million tons from 2014 to 2018 [3] and these products are exported globally such as Netherland, China, India, Turkey and US [4].

Until December 2018, there were approximately 5.19 million hectares of matured oil palm planted area in Malaysia [4] and the total oil palm planted area increased by almost 5 million hectares in 2018 as compared to 2014, which was 53.8 million hectares. Malaysia has 414 number of FFB mills until 2017 which contributes total operation capacity of 112.2 million ton/year. Vast planted area suggests large amount of waste and biomass generated from oil palm mills and plantations.

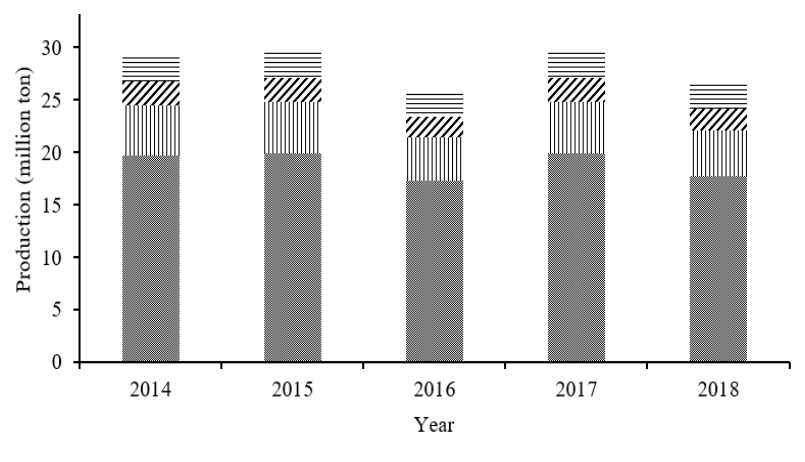

w Crude Palm Oil ॥ Palm Kernel \%Crude Palm Kernel Oil =Palm Kernel Cake

Fig. 1. Production of oil palm products in Malaysia [3].

\subsection{Availability of oil palm biomass and biomass industry value chain}

Common solid wastes which is also known as biomass generated from oil palm plantations include oil palm trunk (OPT) and oil palm frond (OPF) while biomass generated from mills are empty fruit bunch (EFB), palm kernel shell (PKS) mesocarp fiber (MF) and palm oil mill effluent (POME). OPF are the leaves of oil palm tree, which are frequently can be obtained from the

\footnotetext{
* Corresponding author: drsuzana_yusup@utp.edu.my
} 
oil palm trees and inversely, OPT are only available at end of the oil palm tree lifecycle. EFB are the remains solid once the fruits were removed from the fruit bunches. Once CPO was extracted from the fruits, PKS and MF were obtained, from the wasted nuts and pericarps of the oil palm fruits respectively.

Harvesting fresh fruit bunch yield $70 \%$ fruits and $30 \%$ wastes which are the empty fruit bunch and evaporated water. In average, the fruits yield CPO by $43 \%$ and nuts and pericarps contribute about 13 and $14 \%$ respectively [5]. Fig. 2 summarized the amount of waste and biomass collected in year 2010 and forecasted to year of 2020. Oil palm frond shared the largest fraction of solid waste biomass generated which are $57.5 \%$ \& $50.5 \%$ that is equivalent to 46 and 48 million ton in 2010 and 2015 .

The generation is forecasted to increase by 1 million ton in 2020. Detail amount of solid waste and POME as illustrated in Fig. 2 have been obtained by assuming planted area to increase by 1.1 million hectare over 2005 figures and Economic Transformation Program (ETP) upper limit was $28 \%$ area over 2010 [6]. It was estimated over 83 million of dry ton of solid biomass was produced by palm oil industry in Malaysia and it was projected to increase to 110 million ton by 2020 . Increase in volume growth is the major reason for this forecast [6]. If the utilization of oil palm biomass remained unexploited, the amount of generated wastes or feedstock from oil palm industries may outweight the market demand. For instance, the pruned oil palm frond are left discarded in the plantation mostly for nutrient recycling and soil conservation and animal feed [7]. Thus, utilizing oil palm biomass as the feedstock for biochar production will add another market demand for the resources.

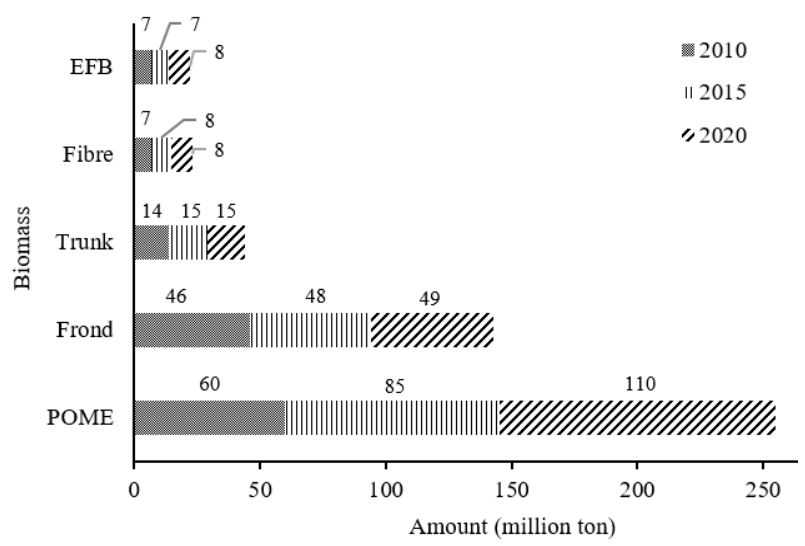

Fig. 2. Biomass production in Malaysia for 2010 and 2015, and forecast generation in year 2020 [6].

A value chain described the technology and infrastructure together with related activities to convert a raw material to a value-added products [8]. The value chain in oil palm biomass industry consists of "availability, transportation and logistics, technology and human capacity, relevant policies and laws, investment and financing, marketing and branding, and accessibility by local and external markets" $[9,10]$. Rubinsin et al. [11] considered challenging uncertainties in value chain for biomass supply, demand, prices, costs, technology, policies, and environmental impacts. Correspondingly,
Malaysian Industry-Government Group for High Technology (MIGHT) [10] has outlined three major strategies for biomass industry value chain in Malaysia which are as follows:

- unlocking biomass feedstock for downstream utilization

- optimised utilization of biomass for sustainable and high value production

- positioning Malaysia as regional hub

These strategies are able to ensure the sustainability of biomass development at industrial scale and were expected to mobilize the participation of SMEs in Biomass Value Chain to create high value products [10].

Owners of oil palm plantation and mills are responsible for the availability of oil palm biomass and its logistic and transportation to downstreams [9]. Therefore, the owner have to consider the cost for harvesting, collecting and transporting oil palm biomass for the production of biochar at industrial scale. The technology applied and manpower are also dependent on the location and availability to retrieve the biomass. For instance, oil palm biomass that have high moisture content such as EFB and MF, are prone to mold and spoilt and therefore earlier pre-treatment for handling this type of biomass is necessary prior leaving the plantations or mills [9].

Futhermore, EFB, PKS and MF are available at the oil palm mills, while OPT and OPF are available at the oil palm plantations [12]. OPF are available at regular basis once FFB are harvested. However, it takes more than 20 years to harvest OPT which is only available due to replanting [12]. MIGHT [10] and Agensi Inovasi Malaysia [6] summarized the range of aquisition cost of biomass in Malaysia. The lowest average cost was illustrated by MF, which was around RM170/ton of dry weight biomass while OPT had the highest average cost, which was approximately RM320/ton of dry weight biomasss. Detail on the cost of biomass is summarized in Fig. 3. This type of cost may contribute to the uncertainties in biomass value chain for biomass feedstock availability, transportation, logistics and technology.

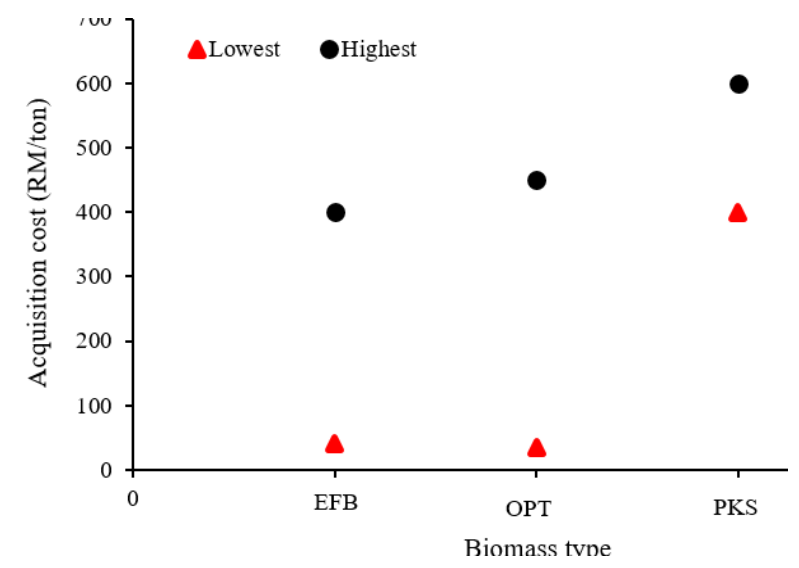

Fig. 3. Range of the lowest and highest cost for acquisition of biomass in Malaysia [10]. 


\section{Thermal conversion technology for biochar production}

The thermal conversion process is divided into 5 stages depending on the conversion phases occur to the biomass and process conditions. Initially, at temperature less than $200^{\circ} \mathrm{C}$, biomass was dried, where mainly moisture was released in vapor phase. Then, devolatilization or carbonization took place once temperature reached 180 to $250^{\circ} \mathrm{C}$, where volatile compound are released and char started to form due to initiation of decomposition. Torrefaction started to occur at $250^{\circ} \mathrm{C}$ and further temperature increased to $300^{\circ} \mathrm{C}$ would initiated pyrolysis process. Gasification proceeded if the temperature was higher than $500^{\circ} \mathrm{C}$. Detail of the conversion phases is illustrated in Fig. 4. The products from thermal conversion process of biomass are liquid, solid and gaseous forms, which was dependant to temperature. Table 1 summarized the distribution of product yield with respect to difference techniques and conditions as reported by Kong et al. [13].

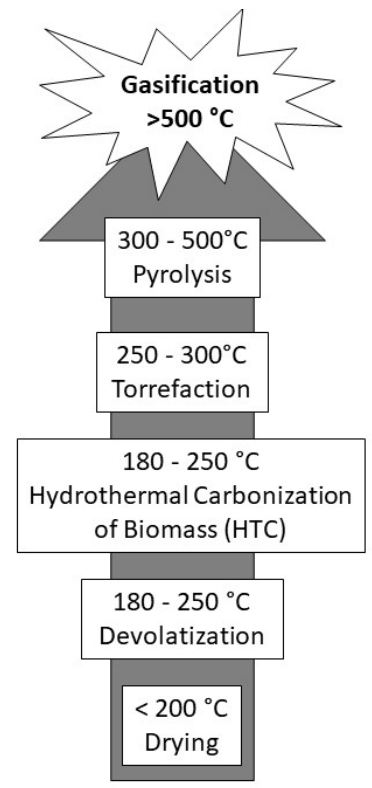

Aromatics, $\mathrm{H}_{2} \mathrm{O}$ syngas and

hydrocarbon formation

Production of charcoal

Deoxygenation, $\mathrm{O}_{2}$ removal and complete hemicellulose decomposition

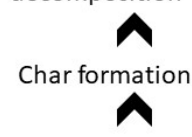

Removal of $-\mathrm{OH}$ structure, organic compounds, $\mathrm{CO}_{2}$ or cellulose decomposition

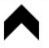

Mainly $\mathrm{H}_{2} \mathrm{O}$ released in vapor phase

Fig. 4. Stages of thermal decomposition of lignocellulosic biomass [14].

Table 1. Condition for pyrolysis techniques and product yield [13].

\begin{tabular}{|c|c|c|c|c|c|}
\hline \multirow{2}{*}{\multicolumn{2}{|c|}{ Techniques }} & \multicolumn{2}{|c|}{ Pyrolysis } & \multirow{2}{*}{$\begin{array}{l}\text { Slow } \\
\text { torrefaction }\end{array}$} & \multirow{2}{*}{$\begin{array}{l}\text { Slow carboni- } \\
\text { zation }\end{array}$} \\
\hline & & Fast & Slow & & \\
\hline \multicolumn{2}{|c|}{$\begin{array}{l}\text { Temperature } \\
\left({ }^{\circ} \mathrm{C}\right)\end{array}$} & $\sim 500$ & $\begin{array}{l}400- \\
500\end{array}$ & $\sim 290$ & $400-500$ \\
\hline \multicolumn{2}{|c|}{$\begin{array}{l}\text { Heating rate } \\
\left({ }^{\circ} \mathrm{C} / \mathrm{s}\right)\end{array}$} & $\begin{array}{l}> \\
1000\end{array}$ & $<1000$ & 1 & 1 \\
\hline \multicolumn{2}{|c|}{$\begin{array}{l}\text { Holding time } \\
\text { (s) }\end{array}$} & 1 & $10-30$ & 1800 & $\begin{array}{l}\text { *hours to } \\
\text { days }\end{array}$ \\
\hline \multirow{3}{*}{$\frac{\partial}{\partial 0}$} & Solid & 12 & 25 & 77 & 33 \\
\hline & Liquid & 75 & 50 & $0-5$ & 30 \\
\hline & Gaseous & 13 & 25 & 23 & 35 \\
\hline
\end{tabular}

Pyrolysis is a typical thermal conversion technology to synthesis biochar particularly from biomass. The process is classified as slow torrefaction and slow carbonization technique. It decomposes the biomass in oxygen-free environment and producing solid, liquid and gaseous products [15]. The solid products are known as biochar while liquid and gaseous products are recognized as bio-oil and syngas, respectively [15]. Pyrolysis is classified by fast pyrolysis, slow pyrolysis or pyrolytic gasification depends on temperature and heating rate [16]. Fast pyrolysis occured at temperature higher than $500^{\circ} \mathrm{C}$ at heating rate higher than $1000^{\circ} \mathrm{C} / \mathrm{min}$, while slow pyrolysis generally occured within hours at temperature less than $500^{\circ} \mathrm{C}$ and heating rate less than $100^{\circ} \mathrm{C} / \mathrm{min}$ [17].

The amount and distribution of product yield from thermal conversion are dependent on the type of thermal techniques. It was observed that slow pyrolysis yield the highest biochar formation compared to fast pyrolysis and gasification technique [18]. An amount of $35 \mathrm{wt} \%$ of solid yield through slow pyrolysis while $10 \mathrm{wt} \%$ of biochar yield was observed for fast pyrolysis and gasification technique respectively [18]. Under certain conditions, it was reported that biochar yield was $77 \%$ and obtained using slow torrefaction technique. In addition, higher mass yield can be observed by using biomass with high ash content yet the product mostly demonstrated low carbon content [19]. High yield of liquid and solid products were obtained for biomass that contained high fraction of volatile matters [20].

Hydrothermal carbonization, microwave carbonization, flash carbonization and torrefaction are among other technology for conversion of biomass [21]. Fire is ignited at high pressure $(1-2 \mathrm{MPa})$ in a packed bed reactor for biomass conversion using flash carbonization process meanwhile microwave carbonization applied microwave radiation to initiate the pyrolysis. Laser and plasma cracking technologies also have been developed as one of the pyrolysis technologies for biomass conversion. However the application using oil palm biomass are quite limited. Plasma is typically used for bacterial sterilisation, and chemical vapour deposition [22]. However, the technology has illustrated potential application for waste treatment and valorisation, bio-fuel production, pollution control or gas treatment [23]. For example, Khongkrapan et al. [24] utilized municipal solid waste (MSW) waste of used office papers, bamboo and plastics using microwave plasma assisted pyrolysis to obtain refuse derived fuel (RDF) in form of char and combustible gas. A modified microwave oven was used as the reactor and generated plasma converted the wastes into and char. The yield of char was $12-21 \%$ with gross higher heating value (HHV) was approximately $39 \mathrm{MJ} / \mathrm{kg}$. Lupa et al. [22] also applied microwave induced-plasma to perform pyrolysis of waste wood and obtained $20.4 \%$ of char production. Rapid heating and cooling of laser pyrolysis technology has enable to avoid the possibility of secondary reaction to occur during pyrolysis reaction [25]. 


\section{Production of biochar from oil palm biomass}

Biochar is a carbon-rich solid material that can be synthesized from lignocellulosic biomass, agricultural waste, sludge or manures. The quality of biochar is determined by its fixed carbon content and biochar composition is crucial to define its application [19]. Physicochemical properties of biochar are dependent on various parameters such as raw material, reaction temperature, heating rate holding time, reaction atmosphere and reactor type [26]. The $\mathrm{pH}$ of biochar also increases with enrichment of ash content [27]. Reaction temperature may close to $1000^{\circ} \mathrm{C}$ to achieve carbon content higher than $90 \%$ which is associated to gasification process [19]. Biochar is graded based on carbon content into three classifications which are Class I for carbon content of $60 \%$ and higher, Class II for carbon content within 30 to $60 \%$ and Class III for carbon content within 10 to $30 \%$ [18].

Production of biochar from green materials such as agricultural waste, forestry waste, and biomass has been applied traditionally as a source for solid fuel. Continuous development and research studies have been performed to enhance energy efficiency and performance of synthesized biochar. Oil palm biomass is one of the most potential feedstock that has been utilized for biochar synthesis. Table 2 summarized the quality of synthesized biochar using different types of oil palm biomass and thermal conversion technologies.

Table 2. Quality of biochar synthesized from oil palm biomass using different thermal conversion technologies.

\begin{tabular}{|c|c|c|c|}
\hline Author & Feedstock & $\begin{array}{l}\text { Technology/ } \\
\text { Condition }\end{array}$ & Quality of biochar \\
\hline [28] & EFB & $\begin{array}{l}\text { Gasification } \\
500-850^{\circ} \mathrm{C}\end{array}$ & $\begin{array}{l}\text { Carbon content: } \\
61.51 \% \\
\text { Calorific value } \\
\text { HHV: } 30.82 \mathrm{MJ} / \mathrm{kg}\end{array}$ \\
\hline [29] & PKS & $\begin{array}{l}\text { Slow pyrolysis } \\
\mathrm{T}: 400- \\
600^{\circ} \mathrm{C} \\
\text { t: } 30-90 \mathrm{~min} \\
\text { r: } 7.3^{\circ} \mathrm{C} / \mathrm{min}\end{array}$ & $\begin{array}{l}\text { Carbon content: } 45- \\
75 \% \\
\text { Surface area: } 106- \\
329 \mathrm{~m}^{2} / \mathrm{g} \\
\text { Adsorption } \\
\text { capacity: } 490- \\
630 \mathrm{~cm}^{3} / \mathrm{g}\end{array}$ \\
\hline [20] & $\begin{array}{l}\text { MF and } \\
\text { OPF }\end{array}$ & $\begin{array}{l}\text { Slow pyrolysis } \\
\text { T: } 400- \\
600^{\circ} \mathrm{C} \\
\text { t: } 15 \mathrm{~min} \\
\mathrm{r}: 10^{\circ} \mathrm{C} / \mathrm{min}\end{array}$ & $\begin{array}{l}\text { Carbon content: } 65- \\
82 \% \\
\text { HHV: } 24.15-24.84 \\
\text { MJ/kg }\end{array}$ \\
\hline [30] & OPF & $\begin{array}{l}\text { Microwave } \\
\text { pyrolysis } \\
\mathrm{T}: 450-700^{\circ} \mathrm{C} \\
\text { Power: } 400- \\
900 \text { Watt }\end{array}$ & $\begin{array}{l}\text { Carbon content: } \\
60.37 \% \\
\text { Surface area: } \\
158 \mathrm{~m}^{2} / \mathrm{g} \\
\mathrm{HHV}: 22.1 \mathrm{MJ} / \mathrm{kg}\end{array}$ \\
\hline [31] & EFB & $\begin{array}{l}\text { Fast pyrolysis } \\
\mathrm{T}: 500^{\circ} \mathrm{C} \\
\text { t: } 20 \mathrm{~min}\end{array}$ & $\begin{array}{l}\text { Carbon content: } 59 \\
74 \% \\
\text { HHV: } 20-25 \mathrm{MJ} / \mathrm{kg}\end{array}$ \\
\hline
\end{tabular}

Oil palm biomass is also known as lignocelllosic material since it is made up of cellulose, hemicellulose and lignin. The fraction of the three components are varied according to the type of biomass. Table 3 summarized the composition of oil palm biomass as reported by Hamzah et al. [32]. Major fraction of biochar is converted from lignin, within 60 to $90 \mathrm{wt} \%$ of the lignin composition in the biomass [13]. PKS illustrated the highest content of lignin among other oil palm biomass, hence it has received major attention as the most potential feedstock for biochar production from oil palm biomass. Hemicellulose and cellulose decomposed at lower temperature compared to lignin which contribute to release of condensable gases and low biochar yield [19].

Table 3. Composition (wt $\%$ dry basis) of components in oil palm biomass [32].

\begin{tabular}{|l|l|l|l|l|l|}
\hline \multirow{2}{*}{ Component } & \multicolumn{5}{|l}{ Type of biomass } \\
\cline { 2 - 6 } & EFB & MF & PKS & OPF & OPT \\
\hline Cellulose & 38.3 & 33.9 & 20.8 & 30.4 & 34.5 \\
\hline $\begin{array}{l}\text { Hemi- } \\
\text { cellulose }\end{array}$ & 35.3 & 26.1 & 22.7 & 40.4 & 31.8 \\
\hline Lignin & 22.1 & 27.2 & 50.7 & 21.7 & 25.7 \\
\hline Extractive & 2.7 & 6.39 & 4.8 & 1.7 & 3.7 \\
\hline Ash & 1.6 & 3.5 & 1.0 & 5.8 & 4.3 \\
\hline
\end{tabular}

\section{Application of synthesized biochar}

Commercialization of biochar using oil palm biomass was considered as a potential development industry in Malaysia, particularly using OPT and OPF [10]. Production of biochar using oil palm biomass does not only benefits the biochar industry but also bring additional profit to oil palm millers, solid fuel industries and waste management sectors. The application of this type of wastes by the industrial players supports the implementation of circular economy in Malaysia.

Biochar has various applications such as for waste water treatment, soil remediation and air pollution control. Application of biochar is varied according to its physicochemical properties. For example, biochar for solid fuel applications should have high calorific value, which dependent to type of feedstock and conversion technology. EFB, OPF and OPT have high moisture content compared to MF and PKS. This characteristic suggest lower calorific value of EFB, OPF and OPT compared to MF and PKS. Table 4 summarized the calorific value and physicochemical properties of oil palm biomass as reported by Hamzah et al. [32]. Biochar with high calorific value suggests efficient solid fuel properties. It is a potential alternative material for substitution of coal applications such as gasification for fuel due to its energy contents. It is reported that a synthesized biochar illustrated LHV of $28.9 \mathrm{MJ} / \mathrm{kg}$ and it is comparable to LHV of the high rank coal [33]. 
Table 4. Calorific value and physicochemical properties of oil palm biomass [32].

\begin{tabular}{|l|c|c|c|c|c|}
\hline Biomass type & EFB & MF & PKS & OPF & OPT \\
\hline $\begin{array}{l}\text { Gross } \\
\text { Calorific } \\
\text { Value (MJ/kg) }\end{array}$ & 18.88 & 19.06 & 20.09 & 15.72 & 17.47 \\
\hline $\begin{array}{l}\text { Moisture } \\
\text { content (wt\%) }\end{array}$ & 67.00 & 37.09 & 12.00 & 70.60 & 75.60 \\
\hline $\begin{array}{l}\text { Ash content } \\
\text { (wt\%) }\end{array}$ & 4.60 & 6.10 & 3.00 & 3.37 & 3.35 \\
\hline $\begin{array}{l}\text { Volatile matter } \\
\text { content (wt } \%)\end{array}$ & 87.04 & 84.91 & 83.45 & 85.10 & 86.70 \\
\hline
\end{tabular}

Rawat et al. [17] used biochar for soil remedies and enhance plant growth. Similarly, Yang et al. [21] also applied biochar for soil remediation. Biochar with greater hydrophobicity and aromaticity, large surface area and microporosity are suitable for removal of organic pollutants such as insecticide and herbicide [27]. Typically this type of biochar is synthesized by full carbonization at pyrolysis temperature higher than $500^{\circ} \mathrm{C}$ [34]. Inversely, partly carbonized biochar which occured at pyrolysis temperature lower than $500^{\circ} \mathrm{C}$, typically has low porosity, $\mathrm{C} / \mathrm{N}$ ratio and higher dissolved organic carbon content, which is more appropriate for application of removing inorganic pollutants [34]. Therefore, application of the synthesized biochar should be determined prior to applying the synthesizing conditions and determining the thermal conversion technology to ensure maximum performance and process efficiency of the synthesized biochar.

\section{Conclusion}

Overall, expansion of oil palm plantation area by 5 million hectares in 4 years by 2018 and forecast oil palm biomass generation to 110 million ton by 2020 indicate a massive availability of oil palm biomass sources for the production of biochar. Efforts by Malaysian government by recommending three major strategies in biomass industry value chain will further promote the potential of oil palm biomass as the feedstock for value-added products, including biochar production. Slow torrefaction process illustrated the most efficient technology for higher yield of biochar which is within $77 \%$. In addition, high fraction of lignin component in PKS and high number of PKS generated also suggesting this type of biomass has the most potential for biochar production. In conclusion, high availability of biomass feedstock with low acquiring cost and high yield of quality biochar using efficient thermal conversion technology, suggests the sustainability and increase commercialization initiatives of biochar production in Malaysia.

\section{Acknowledgment}

Support from Ministry of Education Malaysia through HICoE award to CBBR is duly acknowledged.

\section{References}

[1] A. Idrees, "Malaysian Palm Oil Industry," Malaysian Palm Oil Council (MPOC), 2014. [Online]. Available:

www.mpoc.org.my/malaysia-palm-oil-industry/. Department of Statistics Malaysia, "Gross Domestic Income 2018,” 2019. [Online].

Available:

https://www.dosm.gov.my/v1/index.php?r=colu $\mathrm{mn} /$ cthemeByCat\&cat=266\&bul_id=U1Q2ZFZlc DRRSVJnL2dPT09ESXFOQT09̄\&menu_id=TE 5CRUZC.

[3] MPOC (Malaysian Palm Oil Committee), "2018 Global Palm Oil Market Trends and Opportunities CPO Price Trend - Views from Industry Experts," pp. 2018-2020, 2018.

[4] MPOB, "Oil Palm Planted Area 2018," Malaysian Palm Oil Board (MPOB), 2018. [Online]. Available:

http://bepi.mpob.gov.my/images/area/2018/Area _summary.pdf. [Accessed: 20-Dec-2019].

[5] O. S. Dalton, A. F. Mohamed, and O. C. Aja, "Status Evaluation of Palm Oil Waste Management Sustainability in Malaysia Status Evaluation of Palm Oil Waste Management Sustainability in Malaysia," OIDA Int. J. Sustain. Dev., vol. 10, no. 12, pp. 41-48, 2017.

[6] Agensi Inovasi Malaysia, "National Biomass Strategy 2020: New wealth creation for Malaysia's palm oil industry. Version 2.0," 2013.

[7] N. Abdullah and G. Town, "The Oil Palm Wastes in Malaysia The Oil Palm Wastes in Malaysia," no. December, 2013.

[8] S. M. Jarvis and S. Samsatli, "Technologies and infrastructures underpinning future $\mathrm{CO} 2$ value chains: A comprehensive review and comparative analysis," Renew. Sustain. Energy Rev., vol. 85, no. January, pp. 46-68, 2018.

[9] E. Onoja, S. Chandren, F. I. A. Razak, N. A. Mahat, and R. A. Wahab, "Oil Palm (Elaeis guineensis ) Biomass in Malaysia: The Present and Future Prospects," Waste and Biomass Valorization, no. 0, p. 0, 2018.

[10] MIGHT, "Malaysia Biomass Industry Action Plan 2020," Malaysian Ind. Goverment Gr. high Technol., no. November, pp. 1-53, 2013.

[11] N. James Rubinsin et al., "Optimization of oil palm empty fruit bunches value chain in peninsular malaysia," Food Bioprod. Process., vol. 119, pp. 179-194, 2020.

[12] M. A. Hassan and S. Abd-Aziz, "Waste and Environmental Management in the Malaysian Palm Oil Industry," in Palm Oil: Production, Processing, Characterization, and Uses, O. M. Lai, C. P. Tan, and C. C. Akoh, Eds. AOCS Press, 2012, pp. 693-711.

[13] S. Kong, S. Loh, R. Thomas, S. Abdul, and J. Salimon, "Biochar from oil palm biomass : A review of its potential and challenges," Renew. Sustain. Energy Rev., vol. 39, pp. 729-739, 
2014.

[14] B. Grob and M. Shafiei, Biomass conversion technologies: Catalytic conversion technologies, vol. 57. 2017.

[15] J. S. Cha et al., "Journal of Industrial and Engineering Chemistry Production and utilization of biochar: A review," J. Ind. Eng. Chem., vol. 40, pp. 1-15, 2016.

[16] F. Cheng and X. Li, "Preparation and Application of Biochar-Based Catalysts for Biofuel Production," Catalysts, vol. 8, no. 346, pp. 1-35, 2018.

[17] J. Rawat, J. Saxena, and P. Sanwal, "Biochar: A Sustainable Approach for Improving Plant Growth and Soil Properties," IntechOpen, 2019.

[18] D. Mohan, A. Sarswat, Y. Sik, and C. U. Pittman, "Organic and inorganic contaminants removal from water with biochar, a renewable, low cost and sustainable adsorbent - A critical review," Bioresour. Technol., vol. 160, pp. 191202, 2014.

[19] K. Weber and P. Quicker, "Properties of biochar," Fuel, vol. 217, no. December 2017, pp 240-261, 2018.

[20] G. Kabir, A. T. M. Din, and B. H. Hameed, "Pyrolysis of oil palm mesocarp fiber and palm frond in a slow-heating fixed-bed reactor: A comparative study," Bioresour. Technol., vol. 241, pp. 563-572, 2017.

[21] X. Yang, S. Zhang, M. Ju, and L. Liu, "Preparation and modification of biochar materials and their application in soil remediation," Appl. Sci., vol. 9, no. 7, 2019.

[22] C. J. Lupa, S. R. Wylie, A. Shaw, A. AlShamma'A, A. J. Sweetman, and B. M. J. Herbert, "Experimental analysis of biomass pyrolysis using microwave-induced plasma," Fuel Process. Technol., vol. 97, pp. 79-84, 2012.

[23] J. Luche et al., "Plasma treatments and biomass gasification," IOP Conf. Ser. Mater. Sci. Eng., vol. 29, no. 1, 2012.

[24] P. Khongkrapan, P. Thanompongchart, N Tippayawong, and T. Kiatsiriroat, "Microwave plasma assisted pyrolysis of refuse derived fuels," Cent. Eur. J. Eng., vol. 4, no. 1, pp. 7279, 2014.

[25] M. I. Jahirul, M. G. Rasul, A. A. Chowdhury, and N. Ashwath, "Biofuels production through biomass pyrolysis- A technological review," Energies, vol. 5, no. 12, pp. 4952-5001, 2012.

[26] S. Nomanbhay, B. Salman, R. Hussain, and M. Y. Ong, "Microwave pyrolysis of lignocellulosic biomass - a contribution to power Africa," Energy Sustain. Soc., vol. 7, no. 23, pp. 1-24, 2017.

[27] F. R. Oliveira, A. K. Patel, S. Kumar, D. P. Jaisi, S. Adhikari, and H. Lu, "Bioresource Technology Environmental application of biochar : Current status and perspectives," Bioresour. Technol., vol. 246, no. August, pp. 110-122, 2017.

[28] M. A. Mohd Salleh, N. H. Kisiki, H. M. Yusuf, and W. A. Wan Ab Karim, "Gasification of biochar from empty fruit bunch in a fluidized bed reactor," Energies, vol. 3, no. 7, pp. 13441352, 2010.

[29] S. H. Kong, S. K. Loh, R. T. Bachmann, H. Zainal, and K. Y. Cheong, "Palm kernel shell biochar production, characteristics and carbon sequestration potential," J. Oil Palm Res., vol. 31, no. 3, pp. 508-520, 2019.

[30] A. Hossain, P. Ganesan, J. Jewaratnam, and K. Chinna, "Optimization of process parameters for microwave pyrolysis of oil palm fiber (OPF) for hydrogen and biochar production," Energy Convers. Manag., vol. 133, pp. 349-362, 2017.

[31] M. A. Sukiran, S. O. H. K. Loh, and N. A. B. U. Bakar, "Conversion of Pre-treated oil palm empty fruit bunches into bio-oil and bio-char via fast pyrolysis," J. Oil Palm Res., vol. 30, no. March, pp. 121-129, 2018.

[32] N. Hamzah, K. Tokimatsu, and K. Yoshikawa, "Solid Fuel from Oil Palm Biomass Residues and Municipal Solid Waste by Hydrothermal Treatment for Electrical Power Generation in Malaysia : A Review," Sustainability, vol. 11, no. 3, pp. 1-23, 2019.

[33] W. M. F. W. Mahmood, M. A. Ariffin, Z. Harun, N. A. I. M. Ishak, J. A. Ghani, and M. N. A. Rahman, "Characterisation and potential use of biochar from gasified oil palm wastes," J. Eng. Sci. Technol., vol. 10, no. Spec. Issue on 4th International Technical Conference (ITC) 2014, pp. 45-54, 2015.

[34] M. Ahmad et al., "Biochar as a sorbent for contaminant management in soil and water: A review," Chemosphere, vol. 99, pp. 19-33, 2014. 